\title{
ARBITRAGE AND ADVANCE REFUNDING
}

\author{
MANLY W. MUMFoRD*
}

Municipalities occasionally find themselves in a position where it would be to their financial advantage to redeem their outstanding bonds prior to maturity. The bonds may have been issued at an interest rate higher than that currently prevailing, thus making it advantageous for the issuer to call in the old bonds and issue new securities at the lower rate. ${ }^{1}$ Alternatively, the outstanding bonds may be secured by covenants restricting the government's ability to obtain financing for other needed improvements. ${ }^{2}$ Normally, these covenants can be dissolved once sufficient funds are available to pay the outstanding obligations.

In many cases, however, the issuer is either unable or chooses not to redeem its obligations prior to maturity. By their terms the bonds may not be callable for several years, or they may be callable only on payinent of a substantial redemption premium. In situations such as these, the issuer can often achieve the purpose of the refunding by "advance refunding." This practice involves the issuance of new bonds and the application of the proceeds to the purchase of other obligations, usually United States Government bonds. These are deposited in escrow and will mature as to principal and interest in sufficient amounts and at appropriate times to provide money to pay the bonds being refunded when due.

The advance refunding procedure provides an opportunity for benefits beyond simply achieving the effect of a refunding of outstanding bonds. The potential for arbitrage profits also exists. Because the interest on inunicipal securities is exempt from the federal incoine tax, ${ }^{3}$ the yield on these securities is usually lower than that produced by federal government obligations, the interest on which is taxable. The imposition of income tax on interest paid to holders of federal government bonds generally operates to equalize these yields. Muricipalities, how-

* Partner, Chapman and Cutler, Chicago, Illinois. A.B. 1947, Harvard University; J.D. 1950, Northwestern University.

1. See L. Moak, Administration of Local Government Debt 398-413 (1970).

2. See id. at 413-15.

3. INT. REv. CODE of 1954, § 103(a). The section provides:

Gross income does not include interest on-

(1) the obligations of a State, a Territory, or a possession of the United States, or any political subdivision of any of the foregoing, or of the District of Columbia.... 
ever, are not subject to the federal income tax. ${ }^{4}$ They are therefore able to borrow money at the lower municipal rate of interest and invest this money in higher-yielding federal obligations without being subject to the federal tax burden. It is this practice to which the term "arbitrage" refers.

This Article will trace the development of the arbitrage/advance refunding practice. The first section will briefly discuss the origins of the practice and describe the most widely used advance refunding techniques. State law restraints on advance refundings will also be examined. The second section will deal with the attempts by the Treasury Department to prohibit abuses of the municipalities' privilege to issue tax-exempt bonds without unduly constraining legitimate financial maneuvering. The final section will consider the potential applicability of the federal securities laws to the practice.

\section{The Development of the Arbitrage/Advance REFUNDING SCHEME}

In 1961 the City of Phoenix, Arizona was faced with the need to acquire additional water facilities. Two closed lien revenue bond issues $^{a}$ were outstanding, so that any further water revenue bond financing had to be accomplished on a third lien basis-hardly conducive to selling the bonds at a reasonable rate of interest. The city could have issued general obligation bonds, ${ }^{7}$ but such bonds would have counted against the city's debt limit ${ }^{8}$ and thereby impeded the financing of other

4. Gross income does not include-

(1) income derived from .... the exercise of any essential governmental func-

tion and accruing to a State ...., or any political subdivision thereof, or the

District of Columbia . . . . INT. REv. CODE OF 1954, § 115(a).

5. The term "arbitrage bond" is defined in section 103(c)(2) of the Code. (The section was changed from (d) to (c) by the Tax Reform Act of 1976, Pub. L. No. 94-455.) See text accompanying note 28 infra.

6. A revenue bond is an obligation which is payable solely from the revenues of a particular enterprise and not from the general taxing power of the municipality. The resolution, ordinance, or indenture securing these bonds may or may not permit the issuer to secure future issues with the same source of revenue. Where such a practice is prohibited, the original bonds are called "closed lien" revenue bonds. See L. MoAk, supra note 1 , at 202-05, 331-32.

7. General obligation bonds are those which are secured by the full faith and credit of the issuer and are generally payable from property taxes on all taxable property within the boundaries of the issuer. 15 E. MCQuillin, LAW of Municipal Corporations 477 (3d ed. 1970).

8. A debt limit is a constitutional or statutory restriction upon the incurring of indebtedness, usually measured as a percentage of the assessed valuation of taxable property within the boundaries of the issuer. For example, in Arizona municipal corporations are prohibited from issuing debt in excess of four percent for some purposes and $15 \%$ for others of the value of their taxable property. ARIZ. ConST. art. IX, \& 8 . 
needed projects. A bond dealer suggested that the city consider advance refunding of the first and second lien revenue bonds prior to issuing new water revenue bonds. The third lien bonds would then be treated in the market place as first lien bonds because the holders would not have to fear that in case of a shortage of revenues the prior lien bonds would be paid in full before these third lien bonds would be paid at all. The bond dealer thought that the city might be able to save money as a result of the differential between the rates of interest it would have to pay on the new advance refunding bonds and the higher rates of interest it would receive from the government bonds in which the proceeds would be invested. After the city had agreed to proceed and the enabling legislation had been enacted, the bond dealer and the city put their pencils to paper and found that the savings would be even greater than they had anticipated.

An example will illustrate the profit potential of such an advance refunding scheme. A municipality which issues a $\$ 1,000$ ten-year bond with $4.5 \%$ interest compounded semiannually will be required to repay slightly over $\$ 1,560$ by maturity. If the proceeds of the bond issue were immediately invested in other ten-year bonds paymg $6 \%$ interest, the municipality would receive a total of over $\$ 1,806$. The revenue from the city's investment, therefore, would exceed its total obligation on the refunding bond by $\$ 246$, or almost twenty-five percent of the principal amount of the bond. If such compounding occurs over a twenty-year period, the differential amounts to slightly over $\$ 826$ or more than fourfifths of the principal.

The fortuitous discovery of this arbitrage possibility quite predictably led to a great deal of fimancing, not all of which involved the refunding of outstanding obligations. In perhaps the most ambitious case, an issuer proposed the issuance of $\$ 100,000,000$ of tax-exempt bonds. Approximately $\$ 90,000,000$ of the proceeds were to be applied to the purchase of United States Government bonds which, bearing a higher rate of interest, would provide funds adequate to retire the taxexempt bonds and to leave available the remaining $\$ 10,000,000$ for financial aid to the public schools. It was transactions such as this one which finally aroused the concern of the Treasury Department and which resulted in its repeated attempts to regulate the misuse of the tax exemption for municipal securities. ${ }^{9}$ Prior to discussing these regulations, it will be helpful to note briefly the principal techniques of advance refunding.

9. See note 3 supra and accompanying text. 


\section{Advance Refunding Techniques}

(1) Standard Defeasance. Standard defeasance is the advance refunding scheme most frequently used. With this technique, new bonds are issued in such an amount that a lump-sum investment of the proceeds will return principal and interest sufficient to pay the principal, interest, and redemption premiums, if any, on the bonds being refunded. The proceeds and income from the refunding bonds are used to pay the refunded obligation; the refunding bonds are themselves secured by the source of revenue which originally secured the refunded bonds. ${ }^{10}$

10. The chart below will illustrate the situation if we assume the following set of circumstances: an issuer has outstanding $\$ 10,845,000$ Bonds, bearing interest at five percent per annum and is refunding them with $\$ 10,000,000$ Refunding Bonds which will bear interest at six percent per annum payable semianuually; the proceeds of the Refunding Bonds will be invested in United States Government obligations which also bear interest at six percent per annum; all three sets of obligations mature and bear interest payable on the same dates. Thus, the principal and interest on the refunding bonds will be in the same amounts and payable on the same dates as the respective principal and interest on the government obligations as shown below.

\begin{tabular}{|c|c|c|c|c|c|}
\hline \multirow[t]{2}{*}{ YEAR } & \multicolumn{2}{|c|}{$\begin{array}{l}\text { ESCROW INVESTMENT } \\
\text { INCOME; REFUNDING } \\
\text { BONDS PAYMENTS } \\
\$ 10,000,000 \text { at } 6 \% \\
\end{array}$} & \multicolumn{2}{|c|}{$\begin{array}{l}\text { OLD BONDS } \\
\$ 10,845,000 \text { at } 5 \% \\
\end{array}$} & $\begin{array}{l}\text { CUMULATIVE } \\
\text { SIX MONTHS } \\
\text { BALANCE** } \\
\end{array}$ \\
\hline & Principal & $\begin{array}{c}\text { Principal } \\
\text { and Interest** }\end{array}$ & Principal & $\begin{array}{c}\text { Principal } \\
\text { and Interest* }\end{array}$ & \\
\hline 1 & $\$ 270,000$ & $\begin{array}{r}\$ 300,000 \\
570,000 \\
291000\end{array}$ & $\$ 325,000$ & $\begin{array}{r}\$ 271,125 \\
596,125 \\
263,000\end{array}$ & $\begin{array}{r}\$ 28,875 \\
2,750 \\
31,650\end{array}$ \\
\hline 2 & 290,000 & $\begin{array}{l}581,900 \\
283,200\end{array}$ & 345,000 & $\begin{array}{l}608,000 \\
254,375\end{array}$ & $\begin{array}{r}5,550 \\
34,375\end{array}$ \\
\hline 3 & 305,000 & $\begin{array}{l}588,200 \\
274,050\end{array}$ & 365,000 & $\begin{array}{l}619,375 \\
245,250\end{array}$ & $\begin{array}{r}3,200 \\
32,000\end{array}$ \\
\hline 4 & 325,000 & $\begin{array}{l}599,050 \\
264,300\end{array}$ & 380,000 & $\begin{array}{l}625,250 \\
235,750\end{array}$ & $\begin{array}{r}5,800 \\
34,350\end{array}$ \\
\hline 5 & 345,000 & $\begin{array}{l}609,300 \\
253,950\end{array}$ & 400,000 & $\begin{array}{l}635,750 \\
225,750\end{array}$ & $\begin{array}{r}7,900 \\
36,100\end{array}$ \\
\hline 6 & 365,000 & $\begin{array}{l}618,950 \\
243,000\end{array}$ & 425,000 & $\begin{array}{l}650,750 \\
215,125\end{array}$ & $\begin{array}{r}4,300 \\
32,175\end{array}$ \\
\hline 7 & 385,000 & $\begin{array}{l}628,000 \\
231,450\end{array}$ & 440,000 & $\begin{array}{l}655,125 \\
204,125\end{array}$ & $\begin{array}{r}5,050 \\
32,375\end{array}$ \\
\hline 8 & 415,000 & $\begin{array}{l}646,450 \\
219,000\end{array}$ & 465,000 & $\begin{array}{l}669,125 \\
192,500\end{array}$ & $\begin{array}{r}9,700 \\
36,200\end{array}$ \\
\hline 9 & 435,000 & $\begin{array}{l}654,000 \\
205,950\end{array}$ & 490,000 & $\begin{array}{l}682,500 \\
180.250\end{array}$ & $\begin{array}{r}7,700 \\
33,400\end{array}$ \\
\hline 10 & 460,000 & $\begin{array}{l}665,950 \\
192,150\end{array}$ & 510,000 & $\begin{array}{l}690,250 \\
167,500\end{array}$ & $\begin{array}{r}9,100 \\
33,750\end{array}$ \\
\hline 11 & 485,000 & $\begin{array}{l}677,150 \\
177,600\end{array}$ & 535,000 & $\begin{array}{l}702,500 \\
154,125\end{array}$ & $\begin{array}{r}8,400 \\
31,875\end{array}$ \\
\hline 12 & 515,000 & $\begin{array}{l}692,600 \\
162,150\end{array}$ & 560,000 & $\begin{array}{l}714,125 \\
140,125\end{array}$ & $\begin{array}{l}10,350 \\
32,375\end{array}$ \\
\hline 13 & 545,000 & $\begin{array}{l}707,150 \\
145,800\end{array}$ & 585,000 & $\begin{array}{l}725,125 \\
125,500\end{array}$ & $\begin{array}{l}14,400 \\
34,700\end{array}$ \\
\hline 14 & 580,000 & $\begin{array}{l}725,800 \\
128,400\end{array}$ & 620,000 & $\begin{array}{l}745,500 \\
110,000\end{array}$ & $\begin{array}{l}15,000 \\
33,400\end{array}$ \\
\hline 15 & 615,000 & $\begin{array}{l}743,400 \\
109,950\end{array}$ & 650,000 & $\begin{array}{r}760,000 \\
93,750\end{array}$ & $\begin{array}{l}16,800 \\
33,000\end{array}$ \\
\hline
\end{tabular}


(2) Full cash defeasance. In a full cash defeasance, refunding bonds are issued in such an amount that the proceeds alone are sufficient to pay principal, interest, and redemption premiums on all of the refunded bonds. The revenue previously used to support the refunded bonds is now freed to secure the refunding bonds. This scheme thus differs from the standard defeasance in that there is no reliance on accruing interest from investments to pay the principle of or interest on the refunded bonds. Nevertheless, the money received from the new issue is invested, usually in United States Government bonds, and produces a substantial yield. This yield is often pledged to the payment of a secondary issue of refunding bonds known as special obligation bonds. Thus, in a typical full cash defeasance there will be three related bond issues: the refunded bonds, supported by the proceeds of the refunding bonds; the refunding bonds, supported by the same source of revenue as had previously supported the refunded bonds; and the special obligation bonds, supported by the yield on the investment of proceeds of the refunding issue.

Since the special obligation bonds are secured by the yield on United States Government bonds, they are generally rated highly by the rating agencies and will invariably bear a lower interest rate than the issue secured by the original source of revenue. The arbitrage advantages of a full cash defeasance have been severely circumscribed by Treasury regulations, ${ }^{11}$ and the use of the technique is therefore largely limited to situations in which a mortgage or other indenture securing the old bonds must be released and the trustee refuses to release it until he has received the full amount of principal and interest in cash.

(3) Crossover Refunding. Crossover refunding is a variation on the two defeasance schemes, distinguishable by the way in which the two issues of bonds are secured. Maturing principal of and interest on the

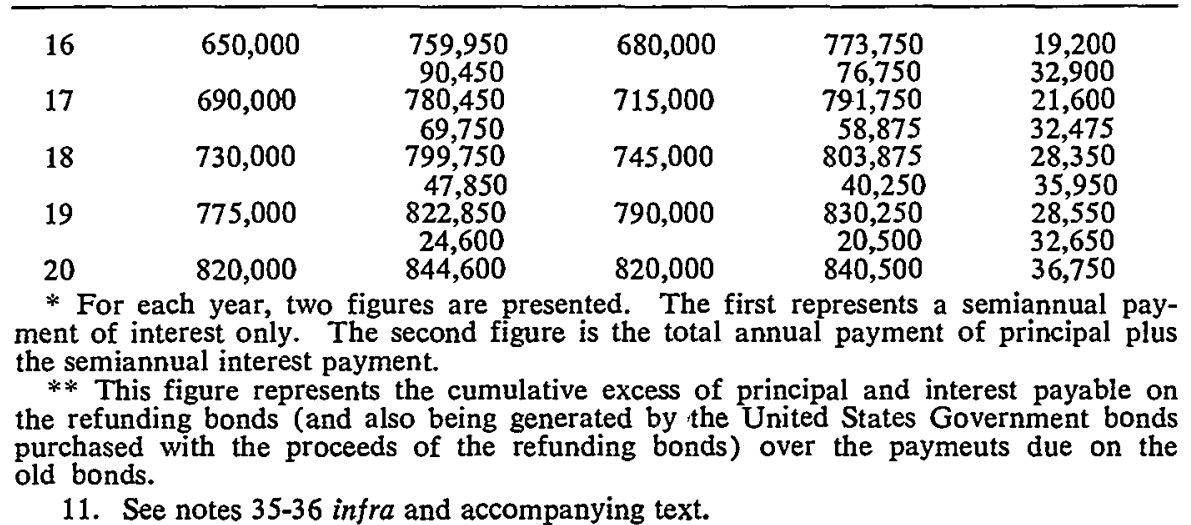

11. See notes 35-36 infra and accompanying text. 
refunded bonds continues to be paid from the same source of income which originally secured them. The interest on the refunding bonds is paid with the interest earned by the escrow investment, which typically involves federal government bonds. No refunding bonds mature until after redemption of the refunded bonds; thereupon the refunding bonds are secured by the same source as the refunded bonds. Although the security to be provided by the government bonds might be viewed as enhancing the marketability of the refunding issue, the use of crossover refunding seems to depend primarily on the preferences of local bond counsel and the purpose to be achieved by the refunding. ${ }^{12}$

\section{State Regulation of Advance Refunding}

No state has forbidden its political subdivisions to engage in advance refunding of its obligations, and in several states the practice has been expressly approved either by statute ${ }^{13}$ or by court decisions. ${ }^{14}$ The flexibility allowed is limited in many states, however. For example, the maximum period for which the proceeds of a refunding issue can remain in escrow may be restricted by law. ${ }^{15}$ Or, if the refunding securities are general obligation bonds, they may be counted against the issuer's debt limit, thus foreclosing other financing options. ${ }^{10}$ This problem has been overcome in some states by judicial decisions permitting the municipality to use a sinking fund established for the payment of the outstanding bonds as an offset against the amount of such bonds in computing compliance with the debt limit. ${ }^{17}$ In other, states, however, this is not possible. $^{1 \mathrm{~s}}$

12. For example, the author has learned that the full cash defeasance method is commonly used in Ohio and Indiana.

13. See, e.g., ARiz. Rev. Stat. ANn. \$ 9-535.01C (Supp. 1975):

[T]he net proceeds [of refunding bonds] may be invested in obligations issued by the United States government, or one of its agencies, or obligations fully guaranteed by the United States government .. . so long as such investments will mature with interest so as to provide funds to pay when due, or called for redemption, the bonds . . to be refunded together with interest thereon and redemption premiums, if any ....

14. See, e.g., Taxpayers and Citizens v. Shelby County, 246 Ala. 192, 20 So. 2d 36 (1944); State v. City of Orlando, 82 So. 2d 874 (Fla. 1955).

15. See, e.g., N.M. Stat. ANN. § 11-6-34.1(G) (Supp. 1975) (only those bonds which mature or are callable within 20 years of issuance of refunding bonds can be refunded absent voluntary surrender by the holders); OKLA. STaT. tit. 69, $\$ 1719$ (b) (1971) (10 years).

16. Sce, c.g., State v. Board of Pub. Instruction, 177 So. 2d 214 (Fla. 1965).

17. See, e.g., City of Los Angeles v. Teed, 112 Cal. 319, 44 P. 580 (1896); Lloyd Corp. v. Bannock County, 53 Idaho 478, 25 P.2d 217 (1933).

18. See, e.g., Doon Township v. Cummins, 142 U.S. 366 (1892); Miles v. State, $96 \mathrm{Ga}$. App. 610, 101 S.E.2d 173 (1957); Murphy v. Spokane, 64 Wash. 681, 117 P. 476 (1911). 
A third potential state law restriction on the practice of advance refunding is a statutory or constitutional requirement for voter approval of bonds. ${ }^{18}$ Soine state courts, however, have held that refunding bonds do not require an election unless the source of payment is altered or the principal anount of the bond issue is enlarged by virtue of the refunding. ${ }^{20}$

Finally, there nay be soine question about permitting the refunded bonds to remain outstanding beyond the first date upon which they are callable for redemption under their terms. In Florida, for example, the first available redemption date must be used, at least as to general obligation bonds. ${ }^{21}$ As a practical matter, whenever it is necessary to refund low interest rate bonds with bonds bearing a higher rate, ${ }^{22}$ it is to the financial advantage of the issuer to let the old bonds run to maturity. The reason for this is that the investments made with the proceeds of refunding bonds will return interest at a rate higher than that payable on the refunded bonds and, therefore, a smaller principal amount of investments can be used to achieve the payment of the old bonds. Note in this connection that even if the refunding bonds bear a higher interest rate than the refunded bonds, the dollar amount of principle and interest payable should be about equal because of the lower principal amount of the refunding issue. ${ }^{23}$ In addition, by waiting until maturity to redeein the refunded bonds, the municipality can avoid the payment of redemption premiuns. When high interest rate bonds are being refunded into lower interest rate bonds, in the absence of arbitrage opportunities, it would be appropriate to call the old bonds on the first available redemption date as a general rule. ${ }^{24}$

19. See, e.g., UTAH CONST. art. XIV, § 3. But see FlA. Const. art. 7, § 12 (specifically exempting refunding bonds from election requirement).

20. See, e.g., Adams v. Pritchard, 88 Idaho 325, 399 P.2d 252 (1965). See also

State v. Citrus Connty, 116 Fla. 676, 692, 157 So. 4, 10-11 (1934).

21. State v. Board of Pub. Instruction, 177 So. 2d 214 (Fla. 1965).

22. See note 2 supra and accompanying text.

23. See note 10 supra.

24. Prior to the issuance of the most recently proposed Treasury regulations in this area, see notes $45-48$ infra and accompanying text, the arbitrage opportunities available through advance refunding worked against this rule, often making it more profitable for the issuer to leave the old bonds outstanding until maturity. Note that in the example shown in note 10 supra, the principal payable each year on the $\$ 10,000,000$ isssue is somewhat less than the principal payable on the $\$ 10,845,000$ issue in the same year; this is due to the fact that a portion of the principal of the larger issue falling due in each year is paid from the excess of the interest on the investments accruing in that year over the interest payable on the refunding issue. If the old issue is called for redemption prior to maturity, the period within which this interest differential will operate to pay part of the principal of the old issue will dimmish and, therefore, a larger principal amount of refunding bonds will be required. 


\section{Federal Regulation of advance Refunding-}

\section{TAX LAW}

Because the arbitrage potential of an advance refunding is a product of the exploitation of the federal tax exemption given to interest on municipal bonds, most of the regulation of the practice has been accomplished through the tax laws. The first public indication that the Treasury Department was aware of the arbitrage problem was given on August 11, 1966 in the form of a Technical Information Release issued by the Internal Revenue Service. The release announced that, pending a study of the problem, the Service would not grant any rulings in situations:

1. Where all or a substantial part of the proceeds of [an] issue (other than normal contingency reserves such as debt service reserves) are only to be invested in taxable obligations which are, in turn, to be held as security for the retirement of the obligations of the government unit.

2. Where the proceeds of [an] issue are to be used to refund outstanding obligations which are first callable more than five years in the future, and in the interim, are to be invested in taxable obligations held as security for the satisfaction of either the current issue or the issue to be refunded. ${ }^{25}$

This release resulted in a moratorium on most advance refundings which remained in effect until the passage of the Tax Reform Act of 1969, which dealt expressly with the problem. ${ }^{26}$ A new provision, section 103(d), was added to the Internal Revenue Code, denying the municipal securities tax exemption ${ }^{27}$ to the interest on "arbitrage bonds." These bonds were defined as

any obligation which is issued as part of an issue all or a major portion of the proceeds of which are reasonably expected to be used directly or indirectly-

(A) to acquire ... obligations ... which may be reasonably expected at the time of issuance . . . to produce a yield over the term of the issue which is materially higher (taking into account any discount or premium) than the yield on obligations of such issue, or

(B) to replace funds which were used directly or indirectly to acquire securities or obligations described in subparagraph (A). ${ }^{28}$

25. TIR-840, U.S. TAX WK.-1966 ANNuAl Digest, at 787.

26. See Pub. L. No. 91-172, $\$ 601$ (a), 83 Stat. 656 (codified at INT. Rev. Code of $1954, \S 103(c))$.

27. See note 3 supra and accompanying text.

28. INT. REv. CODE OF $1954, \S 103$ (d) (2). 
Certain exceptions were made which are not pertinent here, and a special rule declared that an obligation

shall not be treated as an arbitrage bond solely by reason of the fact that-

(B) an amount of the proceeds of the issue of which such obligation is a part may be invested in securities or other obligations which are part of a reasonably required reserve or replacement fund. ${ }^{20}$

The Treasury Department then promulgated a series of temporary and proposed regulations designed to remove arbitrage as an inducement to advance refunding while preserving advance refunding as a legitimate tool of municipal finance. Many of these efforts focused on the definition of two key phrases in the statute: the "major portion of the proceeds" and a "materially higher" yield.

Originally, the Treasury defined the "major portion" as more than five percent of the available proceeds. ${ }^{30}$ The proposed regulations were later amended to raise the "major portion" standard to "an amount in excess of fifteen percent of the original face amount of the issue." 31 This provision complements the limitation on the "reasonably required reserve or replacement fund" to an amount not in excess of fifteen percent of the face amount of the issue. ${ }^{32}$ The significance of these provisions, of course, is that there is no restriction on the use of this reserve, often referred to as the "minor portion" of the proceeds, and therefore these funds can be invested in obligations which produce a high yield. As will be discussed below, this possibility was largely responsible for the continued misuse of advance refunding schemes. ${ }^{33}$

The definition of a "materially higher yield" has also varied. At first, the Treasury proposed that a return more than one eighth of one percent higher than that being paid on the refunding bonds be prohibit-

29. Id. $\S 103(\mathrm{c})(4)$.

30. Proposed Treas. Reg. $\$ 1.103-13$ (a)(3)(ii), 37 Fed. Reg. 10,946 (1972). No final regulations governing arbitrage bonds have ever beeu put into effect. However, prudent bond counsel treat the proposed regulations as law, since such regulations generally contain a provision which would make them retroactive to the date of first publication if finalized.

31. Proposed Treas. Reg. $\$ 1.103-13$ (b) (1)(ii), 40 Fed. Reg. 56,448 (1975). Prior to the 1975 amendments, the Treasury had taken an intermediate position, defining the "major portion" as the lesser of $15 \%$ of the original face amount of the issue or $5 \%$ plus one and a third times one year's debt service. Proposed Treas. Reg. $\S 1.103-$ 13 (a) (3)(ii), 38 Fed. Reg. 10,944 (1973).

32. Proposed Treas. Reg. $\$ 1.103-14(f)(1), 37$ Fed. Reg. 10,954 (1973). This provision has remained the same throughout the series of amendments.

33. See notes 36-37 infra and accompanying text. 

The Internal Revenue Service adopted and unofficially publicized a policy to the effect that if the only advantage of a new issue to an issuer was attributable to the minor portion investinents, the issue would not be regarded as issued for a governmental purpose of the issuer. ${ }^{38}$ Therefore, the entire issue would amount to a violation of the regulations which prescribed that a tax-exempt bond issue may not exceed, by more than five percent, the amount necessary for "the governmental purpose" of the issuer. ${ }^{39}$ Needless to say, it became quite fashionable to find some governmental purpose for an advance refunding to use as a hook upon which to support a transaction that would never have been undertaken by the issuer except for the savings attributable to arbitrage profits and would never have been proposed by the underwriter except for the profits he could get by selling investments at a higher-thanmarket price. ${ }^{40}$

The underwriters' windfall, however, eventually came to an end. Two forces were responsible for this occurrence: In the first place, resentment grew within the financial community (generated primarily by those underwriters who were not engaging successfully in advance refundings) against the use of advance refundings, particularly in situations where the transaction did little real good for the issuer other than generating arbitrage profits. Additionally, many of the successful underwriters felt that they were simply not entitled to such a large profit and expressed willingness to take a considerably smaller return by giving away some of the windfall profit. ${ }^{41}$ The profit with which these underwriters were willing to part could not be rebated to the issuer, for such a gift would amount to increasing the yield on the investments made with the issuer's bond proceeds. Two potential objects of beneficence were left: charity and the federal government. Not surprisingly, many local governments chose to have the excess profit, or a substantial part thereof, go to local charities rather than to Washington. However, it was unclear whether such a gift to a local charity would be regarded as a

38. This policy was not published in any official report, but it became known to various bond counsel through discussions with members of the staff of the Internal Revenue Service and through speeches by members of the staff of the Internal Revenue Service to institutes at which bond lawyers were present. The wisdom of promulgating policy in this fashion is outside the scope of this paper.

39. Proposed Treas. Reg. § 1.103-13(b)(5)(iv), 40 Fed. Reg. 56,448 (1975).

40. Such governmental purposes included the combining of principal and interest payments on a number of different bond issues into payments on a single larger bond issue, shortening or lengthening the maturities of the issuer's indebtedness and modifying covenants securing bonds (even though the issuer was perfectly happy with the existing covenants at the time of the refunding but might later want to take advantage of some relaxation of those covenants).

41. See The Weekly Bond Buyer, Aug. 30, 1976, at 1. 
gift to the political subdivision (and therefore a prohibited increase in the yield on the issuer's investments). ${ }^{42}$

The municipal issuer then was faced with the problem of having to find prudent investments for the refunding bond proceeds which returned interest no higher than that payable on the bonds themselves. If the proceeds were to be invested in safe, high-yield federal securities, the excess profit margin had to be appropriated by someone other than the issuer-typically the underwriter, in the form of tainted windfall profits. As soon as this dilemma became apparent, the Treasury Department provided a way out by offering a special series of government bonds ("book entry" bonds) available only to state and local governments. The interest on these bonds is less than that paid on other federal securities, and is commensurate, rather, with the prevailing municipal bond rate. ${ }^{43}$ These bonds have the additional attraction of solving the problem, common to all fixed-maturity securities, of the bonds maturing before the bondholder can use the funds. This is accomplished by permitting the purchaser to set the maturity date. Municipalities engaged in a refunding are thereby enabled to avoid having to leave any money uninvested during the period between the maturity of the investment and the maturity of the bonds being refunded. ${ }^{\text {th }}$

The most recent amendments to the proposed arbitrage regulations, issued on October $29,1976,{ }^{45}$ go even further toward insuring

42. If the windfall profit were to be given to a charity which performs a function that the issuer of the bonds would otherwise perform, such a gift might result in reducing the burden to the issuer and thus constitute a prohibited return to the issuer on the issuer's investment. For example, a gift to a county hospital might reduce the amount that the governing body of the county would have to appropriate to run the hospital.

43. Book entry bonds can be bought at any rate of interest not higher than oneeighth of one percent below the going rate of interest for other government bonds of the same maturity. 31 C.F.R. § 344.1(b) (2) (1976).

44. At the same time the Treasury announced the new book entry bonds, it also proposed to the Congress the enactment of a law which would provide that a political subdivision could obtain a one-eighth of one percent arbitrage advantage on the entire escrow investment if it used book entry bonds exclusively. U.S. DEP'T OF TREASURY, Proposals for Tax Change 148 (1973). This was calculated to eliminate the windfall profit to underwriters by making it more profitable to municipalities to give the windfall to the federal government. The proposal was made shortly before the controversy involving the Chairman of the House Ways and Means Committee affected the work of that committee, and no action was taken by the Congress.

45. The proposed regulations provide that as to the material announced by a press release on September 24, 1976, such regulations would be effective from and after that date; as to certain other matters not mentioned in the press release, the regulations would be effective October 29, 1976, with a grace period until November 29 (or 30 days later in some circumstances) with respect to bonds sold before October 29. Proposed Treas. Reg. $\$ 1.103-13$ (a)(3), 41 Fed. Reg. 47,682 (1976). 
that alinost all advance refunding will be accomplished through the use of book entry bonds. These rules provide that in calculating the yield on the obligations acquired with the major portion of the proceeds of a refunding issue for the purpose of determining whether such yield is "materially higher" than that of the refunding issue, the "market price" of the obligations, as deternined by reference to an established market, shall be used. ${ }^{46}$ Where there is no established market for such obligations, the refunding bonds shall be presuined to be arbitrage bonds. ${ }^{47}$ The effect of this provision is to eliminate the potential windfall to underwriters since the yield on escrow investments can no longer be artificially lowered.

In addition, the new amendments prohibit mvestment of the minor portion of the refunding bond proceeds in higher yielding obligations. ${ }^{48}$ Thus, the Treasury has removed much of the incentive for underwriters to promote advance refundings and much of the incentive for issuers to advance refund outstanding bonds, except for legitimate governmental purposes sufficient in themselves to justify a refunding.

Nevertheless, a close examination of the new amendments reveals a potential means for a bond dealer, acting as fiscal advisor, to extract an added financial benefit from an advance refunding. In computing the yield on both the refunding bonds and the bonds purchased with the proceeds of the refunding bonds, "the present value of the administrative costs of issuing, carrying and repaying the issue and the present value of the administrative costs to be incurred in purchasing, carrying and selling or redeeming acquired obligations shall be taken into account as a premium or discount . . ." ${ }^{49}$ That is, if the issuer incurs administrative costs in issuing the refunding bonds it may treat the present value of those administrative costs as a discount on the principal amount of the bonds; if it incurs administrative costs in acquiring the escrow investments (the "acquired obligations") it may treat the present value of such administrative costs as a premium on the purchase price of the escrow investments in computing the yield. One of such expenses is a fiscal advisor's fee.

The choice of whether to allocate the costs of an advance refunding to the refunding bond issue or the escrow investment becomes significant if the refunding bond issue and the escrow investment run for substantially different periods of time. For example, assume that a municipality

46. Proposed Treas. Reg. $\$ 1.103-13$ (c)(1)(iii)(A), 41 Fed. Reg. 47,684 (1976).

47. Proposed Treas. Reg. $\S 1.103-13$ (c)(1)(iii)(B), 41 Fed. Reg. 47,684 (1976).

48. Proposed Treas. Reg. $\$ 1.103-14$ (e)(5)(ii)(B), 41 Fed.' Reg. 47,685 (1976).

49. Proposed Treas. Reg. $\S 1.103-13$ (c)(1)(ii), 41 Fed. Reg. 47,683 (1976). 
issues $\$ 1,000,000$ of six percent refunding bonds which will mature in twenty years. The proceeds of this issue are to be deposited in escrow and invested in government bonds payable in ten years. The rate of return on these government bonds will be limited by the arbitrage regulations to the interest rate payable on the refunding bonds ${ }^{60}$ - six percent in this case. Assume further that the administrative costs of this plan are $\$ 10,000$, or one percent of the refunding issue. If these costs are treated as a discount on the sale of the refunding bonds, the interest rate payable, which determines the maximum permissible yield on the escrow investment, will be calculated on the basis of $\$ 990,000$. In other words, although the total interest payable is a fixed constant, it will be treated as interest on an issue of $\$ 990,000$ rather than $\$ 1,000,000$ in determining the yield used in fixing the investment ceiling -in this case $6.0871 \%$. The issuer can recoup only part of these costs, however, by purchasing escrow investments with a yield equal to this higher yield on the refunding bonds. The increased yield on the ten year escrow investment would have a present value of only $\$ 6,480$, so that less than two-thirds of the costs allocated to the refunding issue would be recovered.

If, on the other hand, the administrative costs are treated as a premium on the cost of the escrow investment, the maximum permissible yield on the investment will be figured on the basis of six percent of $\$ 1,100,000$. Since only $\$ 1,000,000$ will actually be invested, the municipality will be able to obtain a return of $6.14 \%$ without exceeding its overall limit. The present value of this increased yield on the escrow investments should be sufficient to enable the issuer to recover all of its administrative costs over the course of ten years. ${ }^{51}$ The allocation of these costs, therefore, can have a significant impact on the financial advantage to be gained from undertaking an advanced refunding. Perhaps more importantly, this example illustrates that in spite of the restrictive new regulations, there is still room in which an imaginative fiscal advisor can operate. ${ }^{52}$

50. Proposed Treas. Reg. $§ 1.103-13$ (b) (5), 40 Fed. Reg. 56,448 (1975). See text accompanying note 35 supra.

51. If, as is sometimes the case, the escrow runs for a longer period than the refunding issue, the full administrative costs can be recovered by taking the converse course and treating them as a discount on the proceeds of the refunding bonds, thereby increasing the permissible yield on the escrow investments.

52. Perhaps for this reason, the Treasury has placed a special limitation on the amount of fiscal agent fees which can be included in the administrative costs of an advance refunding. Such fees cannot exceed three percent of the principal face amount of the refunding issue below $\$ 1,000,000$ plus one percent of the face amount of the refunding issue in excess of $\$ 1,000,000$. Proposed Treas. Reg. $\$ 1.103-13$ (c)(1) (ii), 41 
Finally, it should be noted that the proposed regulations affect certain practices which are normally adopted without regard to the possibility of arbitrage. For example, municipal issuers often create a reserve out of a portion of the proceeds of a bond issue which is capitalized and held for payment of the bonds when due. If these bonds are refunded, this capitalized reserve may be treated as "transferred proceeds" of the refunding bond issue and, therefore, subject to the same yield restrictions as the actual proceeds of the new issue when the refunded bonds are discharged. ${ }^{53}$

Another common advance refunding practice is to retain uninvested funds in the escrow account for short periods of time. For example, in an ordinary advance refunding there is, at the end of each date upon which principal or interest of the old bonds is to be paid, a balance left in the escrow account due to the fact that the maturing escrow muestments and interest thereon will never exactly meet the amounts of principal and interest falling due on the bonds being refunded. ${ }^{54}$ This remaining balance is typically retained in the escrow account until the next interest payment date, when it will be combined with other money derived from maturing principal and interest on the investments to make the next payment of principal and interest on the refunded bonds. The bank holding these running balances is normally instructed not to invest them so that there will be no danger of the yield on escrow mvestments exceeding the amount permitted by the arbitrage regulations. However, under the new amendments, this direction not to invest the money may amount to a transfer of arbitrage profits to the bank. The issuer can avoid this problem by directing the bank to invest such balances, to the extent possible, in non-interest-bearing obligations of the United States. Perhaps as demand for such obligations becomes known, they will become available in book entry form, as their issuance would obviously be beneficial to the federal government.

An additional problem occurs when an issuer fimds it necessary to refund low interest rate bonds into higher interest rate bonds and,

Fed. Reg. 47,683 (1976). Within this limitation, however, there is little incentive to minimize fiscal agent fees. As described above, where the period of the escrow is equal to or longer than the duration of the refunding bonds, the issuer will be able to recover all of its admiuistrative costs through the increased yield obtainable by wisely allocating those costs. See notes 49-51 supra and accompanying text. The Treasury may be able to impose further restrictions on the anount of the fiscal agent's fee under section 1.10313 (c)(1)(ii) which prohibits the issuer from taking into account as legitinate fees "amounts designed to divert arbitrage to the recipient." However, the problems of proof under that provision seem considerable.

53. Proposed Treas. Reg. $\$ 1.103-14$ (e) (2) (ii), 40 Fed. Reg. 56,450 (1975).

54. See the table in note 10 supra, particularly the column headed "Cumulative Six Months Balance." 
therefore, must use the interest on the escrow investments to pay part of the principal of the bonds being refunded. Interest on the book entry government bonds in which the escrow funds are typically invested is payable semiannually while the principal of the bonds being refunded is, in most cases, payable annually. That portion of interest on the escrow investments which falls due on an interest payment date other than a principal payment date and which is to be used to pay part of the principal of the bonds being refunded, therefore, inust lie idle for six months. This idle money is likely to be subject to the same restrictions against either investment or holding in a bank deposit as the cash balances mentioned in the preceding paragraph. The fact that this money cannot be reinvested means that the issuer will have to issue a larger amount of refunding bonds than it otherwise would because it cannot get the advantage of the earnings on such idle money. This particular problem could be solved to the advantage of both the federal government and the issuer of the refunding bonds by the creation of book entry bonds paying interest annually or semiannually at the option of the purchaser.

In summary, the new amendments to the proposed regulations should bring at least a temporary halt to the use of advance refundings as a means of obtaining arbitrage profits. In addition, the regulations will affect some practices employed in advance refundings undertaken for legitimate governmental purposes.

\section{Federal Regulation Under the Securities LaWs}

Since advance refunding schemes have not been entirely forbidden, and since many advance refunding bonds remain outstandimg, a discussion of the potential applicability of the federal securities laws to transactions involving these bonds is appropriate.

Section 17(a) of the Securities Act of $1933,{ }^{55}$ which prohibits fraud in the sale of securities, and section $10(b)$ of the Securities

\section{Section 17 (a) provides that:}

It shall be unlawful for any person in the offer or sale of any securities by the use of any means or instruments of transportation or communication in interstate commerce or by the use of the mails, directly or indirectly-

(1) to employ any device, scheme, or artifice to defraud, or

(2) to obtain money or property by means of any untrue statement of a material fact or any omission to state a material fact necessary in order to make the statements inade, in the light of the circumstances under which they were made, not misleading, or

(3) to engage in any transaction, practice, or course of business which operates or would operate as a fraud or deceit upon the purchaser. Securities Act of 1933, §17(a), 15 U.S.C. $\$ 77 q(a)(1970)$. 
Exchange Act of $1934,{ }^{56}$ which applies to both the purchase and sale of securities, seem to impose a duty on an underwriter promoting an advance refunding to disclose to the municipality all material facts concerning the transaction. ${ }^{57}$ Regardless of whether the proceeds of the refunding bonds are invested in regular Treasury bonds or in book entry bonds, the facts which must be disclosed are similar.

One of the material facts certamly is that the investments are being sold to the issuer at a price substantially higher than the market price for like investments of equivalent yield..$^{58}$ The issuer should also be apprised of the foreclosure of future financing opportunities. For example, if interest rates continue to fall after an advance refunding, the municipality will not ordinarily be able to obtain the approval of bond counsel to undertake a second advance refunding of the same underlying indebtedness until the escrow investment is terminated. ${ }^{59}$ Thus, the issuer could not take advantage of the reduction in interest rates until the first call date of the new refunding bonds, when it could simply refund those obligations. Likewise, when a revenue bond issue is advance refunded, the opportunity for a further advance refunding in order to modify a burdensome covenant is gone until the first call date for the refunding bonds or the termination of the escrow.

One factor which is not quite so apparent should also be considered. Typically, the issuer must rely entirely on the calculations of the

56. Section $10(\mathrm{~b})$ makes it unlawful for any person

[t]o use or employ, in connection with the purchase or sale of any security .... any manipulative or deceptive device or contrivance in contravention of such rules .... as [the SEC] may prescribe . . . . Securities Exchange Act of $1934, \$ 10(\mathrm{~b}), 15$ U.S.C. $\$ 78 \mathrm{j}(1970)$.

Pursuant to this section, the SEC promulgated Securities Exchange Act Rule 10b-5, 17 C.F.R. $\S 240.10 \mathrm{~b}-5$ (1976), which proscribes with regard to the purchase or sale of any security the same practices prohibited by section 17(a) of the Securities Act of 1933. See note 55 supra.

57. In some situations, the entrepreneur promoting the scheme will neither buy the refunding bonds nor sell the government bonds to the issuer but will merely take a fee as a fiscal advisor to the issuer. Although the 1933 and 1934 Acts do not apply to a financial advisor (except in the case of a conspiracy between the financial advisor and such buyer or seller), the financial advisor could be found to have a fiduciary relationship with the issuer. See City of Miami v. Benson, 63 So. 2d 916 (Fla. 1953).

58. See text accompanying notes 35-36 supra.

59. Whenever an advance refunding occurs, there are two bond issues outstanding representing the same borrowing by the issuer. Adding a third such issue by a "double advance refunding" has been neither upheld nor struck down by any court of last resort (although such a case is now being appealed to the Supreme Court of Florida), nor do statutes shed any light on the subject. Since there seems to be no reason why the pyramiding of advance refundings must stop with a double advance refunding, it is conceivable that the number of bond issues representing the same underlying borrowing could be expanded indefinitely if not stopped after the first one. 
underwriter or fiscal advisor to determine whether and how much will be saved as a result of the advance refunding. The underwriter or fiscal advisor will often be able to manipulate the maturity schedule of the refunding bonds to allow such savings to be realized either immediately, at regular intervals, or upon the maturity of the refunding bonds. The issuer should be informed, therefore, of both the ultimate savings and the present value of such amount prior to undertaking the refunding. This problem is alleviated under the new regulations which require the issuer to include in its certification of a refunding issue ${ }^{30}$ issued for the purpose of saving interest a statement of the interest to be saved by the refunding and the present value of that interest. ${ }^{\text {.1 }}$

One other practice could also lead to liability under the anti-fraud provisions if all of the facts are not fully disclosed to the purchasers of the refunding bonds. Prior to the creation of book entry bonds, it was sometimes found expedient to invest the proceeds of refunding bonds in certificates of deposit of a bank. ${ }^{02}$ The bank's debt as represented by these certificates is normally secured by U.S. government bonds which it holds. Therefore, such certificates are generally thought to be quite safe. There is, however, a significant danger associated with these instruments. Typically, the collateral is lodged with a bank other than that issuing the certificate. If the issuing bank should fail, the bank holding the collateral may not be able to release it until given permission by a bankruptcy court, which may take a considerable amount of time if other creditors of the defunct bank dispute the right of the certificate holder to the collateral. In the meantime, the advance refunding escrow would not be receiving the funds necessary to retire the refunded bonds. The holders of these old bonds, who are seldom asked to consent to an advance refunding, will still be entitled to realize on the security shown on the face of their bonds (e.g., utility revenues or a special tax levy). As discussed earlier, however, this source of revenue is normally used to secure the refunding bonds since income from the escrow investments is counted on to repay the refunded bonds. ${ }^{63}$ The holders of the refund-

60. The proposed arbitrage regulations permit the issuer of refunding bonds to certify in the bond indenture that the proceeds of the issue "will [not] be used in a manner that would cause such obligations to be arbitrage bonds." Proposed Treas. Reg. $\S 1.103-13$ (a)(2)(ii), 38 Fed. Reg. 10,945 (1973). The holders of these bonds can rely upon this certification with regard to whether the interest on the bonds is exempt from federal income tax. Id.

61. Proposed Treas. Reg. $\$ 1.103-13$ (a) (2) (ii), 41 Fed. Reg. 47,682 (1975).

62. Typically, certificates of deposit are quite flexible as to the denomination and date of maturity, so they match up nicely to the requirements of the escrow account in paying out the principal of and interest on the refunded bonds.

63. See notes 10-12 supra and accompanying text. 
ing bonds, therefore, are left in a precarious position. If, for example, the bonds were issued to advance refund utility revenue bonds, the holders would have only a junior lien on the utility revenues. Their bonds would be virtually unsecured unless the issuer could be persuaded to increase utility rates in an amount sufficient to provide funds to repay both the refunding and refunded issue. Whether the bondholders could compel such action is uncertain. ${ }^{64}$ In any event, it is clear that the holders of the refunding bonds will have suffered considerable injury and may be able to recover damages under the anti-fraud provisions if the material facts about the transaction were not made known to them at the time of their purchase.

\section{CONCLUSION}

The possibility of deriving arbitrage profits through an advance refunding of municipal obligations began as simply an attractive side effect of engaging in such a transaction but quickly became the major impetus for a great deal of municipal financing. By issuing tax-exempt bonds at a low interest rate and investing the proceeds in higher-yielding obligations, municipalities were able to obtain financial benefits far in excess of the interest savings normally achieved by a refunding. The Treasury Department's efforts to control this abuse of the special tax status given municipal obligations were initially unsuccessful, primarily because of the failure to remove the incentives to underwriters and other fiscal advisors to promote advance refundings. The most recent regulations, however, severely limit the gains to be made by either the underwriters or the municipal issuers and should bring to a halt advance refundings undertaken for other than legitimate purposes. Nevertheless, a close examination of these regulations reveals that the possibility of some "extra" profits for the fiscal advisor remains.

Finally, whatever the effect of the recently proposed regulations, large amounts of previously issued refunding obligations are presently outstanding. Should the distribution of these securities be challenged under the anti-fraud provisions of the federal securities laws and be subjected to the intense judicial scrutiny typically associated with such actions, the failure to make full disclosure of certain facts concerning these issues could result in liability for both the issuers and underwriters.

64. See generally Note, Creditors' Remedies in Municipal Default, 1976 DukE L.J. 1363. 
